\title{
POLYMERIZED PACKTECH INDUSTRY AND GROWTH FACTORS
}

\author{
BINDU SHARMA ${ }^{1} \&$ DR. SHIKHA SHARMA ${ }^{2}$ \\ ${ }^{1}$ Ph.D. Scholar, Amity Business School, India \\ ${ }^{2}$ Professor, Amity Business School, Amity University Rajasthan, India
}

\begin{abstract}
Polymerized Packtech industry cited NIC code 22203 as a specific derivate of polymerized packaging items for bags, lay flats, and woven sacks for the precise study of the Packtech industry. Among the wide variety of plastic polymers, the study focused on the Society of Plastic Industry codes 2, 4, and 5. These codes resemble the thermoplastic flexible packaging/Packtech products for user industries like food and grain industries, automobile, medical industry, clothing, and accessories industry, building and accessories industry, e-commerce industry and local venders, as high-density polyethylene (HDPE), low-density polyethylene(LDPE) and polypropylene(PP). The material HDPE, LDPE, and PP are versatile functional applications that comprise value addition through the packaging of user industry products. The study carries out the consumption growth of these materials in manufacturing units of the Packtech industry at the regional level, especially for Jaipur district. The study entails the industry growth attributes (IGA) for the industry to estimate opportunities and challenges within the industry to create a roadmap for the circular industry system to enhance the green production in Rajasthan, Jaipur, and minimize the Packtech waste as landfill. The industry growth attributes are selected on the basis of the bibliometry. To evaluate the significant difference between attributes in concern of consumption growth, Friedman test carried out for hypothesis testing further post hoc testing use for evaluating pair wise difference to identified most effective attributes for consumption growth of the Packtech industry. The primary and secondary data were used for the study. The total sample taken 21 manufacturing Packtech industry among them 18 responses evaluated for the study.

KEYWORDS: Polymerized Packtech Industry Structure, Material Consumption, Consumption Growth, Industry Growthpull \& Push Factors
\end{abstract}

Received: Jun 08, 2020; Accepted: Jun 28, 2020; Published: Sep 11, 2020; Paper Id.: IJMPERDJUN20201165

\section{INTRODUCTION}

At the end of the 20th century, Packtech became one of the most universally-used and multipurpose product in the global economy. Today, Packtech is utilized in more and more industrial applications and they have become essential to our modern economy. The Packtech industry has served their product almost all other industry from agriculture to service industry. The product mix consider under Packtech industry are Bags, Layflats and woven Sacks of LDPE/HDPE/PP (Bindu Sharma, 2020). These product mixes are numerous applications in food and grain industry, building and construction industry, automotive industry, medical industry, agriculture industry clothing and accessories industry and retail \& service sector (E-Commerce). Polymerized Packtech industry structure is covers. A) Polymer and compound/resin Supplier/ petrochemical byproduct manufacture. B) Packtech manufacturer. C) Packtech supplier.

The petrochemical industry is highly dominated by only a few players in Indian economy; however, Top 5 companies are listed as below (Compare Infobase Limited, 2011):1) Reliance Industries Ltd. 2) Haldia 
Petrochemicals Ltd. 3) Indian Oil Corporation 4) Gas Authority of India Limited 5) National Organic Chemical Industry Ltd.

Top 5 players are RIL with 19\%, IPCL 24\%, HPL 19\%, Gail 4\% and Finolex 5\% which acquire $70 \%$ polymer manufacture market share of total market. These are major supplier of plastic raw material for Packaging, consumer goods, pipe and sanitary fittings, medical articles for hygiene, cleanliness and flexible body parts industries in bulk.

Packtech manufacturers, NIC code 22203(National Industrial Classification, 2008), are only considered which manufacturing plastic bags, Layflats and woven sacks through LDPE/HDPE and PP for polymerized Packtech industry. Concentrations of these manufacturers are 22 in Jaipur among 52 in Rajasthan. Packtech suppliers have concentrated 30 units in Jaipur. The main objectives of the research identify the Packtech industry growth factors for create a roadmap for sustainable industry and minimize the adverse impact on society from the industry to develop circular system. The current research extents for regional level to Packtech industry cluster of Jaipur district to enhance the green production in the industry with minimization of Packtech waste and reduce the environmental impact.

\section{MATERIAL CONSUMPTION}

Material consumption (Lieber, 2016) has two indicators 1) Domestic Material Consumption (DMC) and 2) Raw Material consumption (RWC). The materials needed along the supply chains of traded goods not account in DMC, which has restriction from an analytical point of view. Alternatively, the indicator Raw Material Consumption (RMC), counts for the physical quantity of materials required along the supply chains of all goods and services finally consumed. The concept thinks globally and act locally (Collier, 1997) stressed in today's economic situation where sustainability (Feil, 2019) is major concern for industry and eco system. The material consumption growth(Giljum, 2014) indicates the growth of economy, in this study estimate the Packtech material consumption for Jaipur to analyzed the physical quantity HDPE/LDPE/PP used by micro and small Packtech industries, in amount and quantity (in metric tons).

Table 1: Analysis Cumulative Consumption based on 2018 in Amount (in caror) and Quantity (in metric tons)

\begin{tabular}{|l|c|c|c|c|}
\hline Packtech Industry & Consumption in Amount & Percentage & Consumption in Quantity & Percentage \\
\hline Micro Industries & 10.33 & 5 & 1,730 & 5 \\
\hline Small Industries & 198.17 & 95 & 30,606 & 95 \\
\hline Total & 208.5 & 100 & 32,336 & 100 \\
\hline
\end{tabular}

Source: Primary Data from PI by Author

This table shows the Packtech raw material consumption in metric tons by Packtech industries (based on 2018 in crore) data provided by the account section of each respondent manufacturing unit. Small scale Packtech industries have major consumption of raw material in both amount and quantity. It consist $95 \%$ of total consumption of Packtech Industry while micro industries have lesser consumption only $5 \%$ due to plant capacity.

Table 2: Analysis of Material Wise Consumption by Industry

\begin{tabular}{|c|c|c|c|c|c|}
\hline Material & Micro Industry Used & Percentage & Small Industry Used & Percentage & Total Industry Used \\
\hline HDPE & 13 & 72 & 5 & 28 & 18 \\
\hline LDPE & 2 & 29 & 5 & 71 & 7 \\
\hline PP & 3 & 36 & 5 & 64 & 8 \\
\hline
\end{tabular}

Source: Primary Data from PI by Author

This table shows the Material used status in reference of HDPE, LDPE and PP based on detail provided by Rajasthan Plastic association. HDPE has versatile material which used all manufacturing units while LDPE material used 
only 39\% manufacturing units in which only $29 \%$ LDPE used micro industries and $71 \%$ used by small Packtech industries. PP material used $36 \%$ by micro industries while $64 \%$ used by small industries and total $45 \%$ pp material used at the industry level.

\section{MARTIAL CONSUMPTION GROWTH}

Domestic material consumption (Weisz, 2006) shows the local material flow within the industry, Packtech industry Jaipur product flow in various user industries as food and grain industry, automobile industries, textile and clothing industry, Medical industries, building and accessories industries E-commerce and local venders. Average consumption of Packtech industry shows the continues growth of polymerized Packtech raw material consumption.

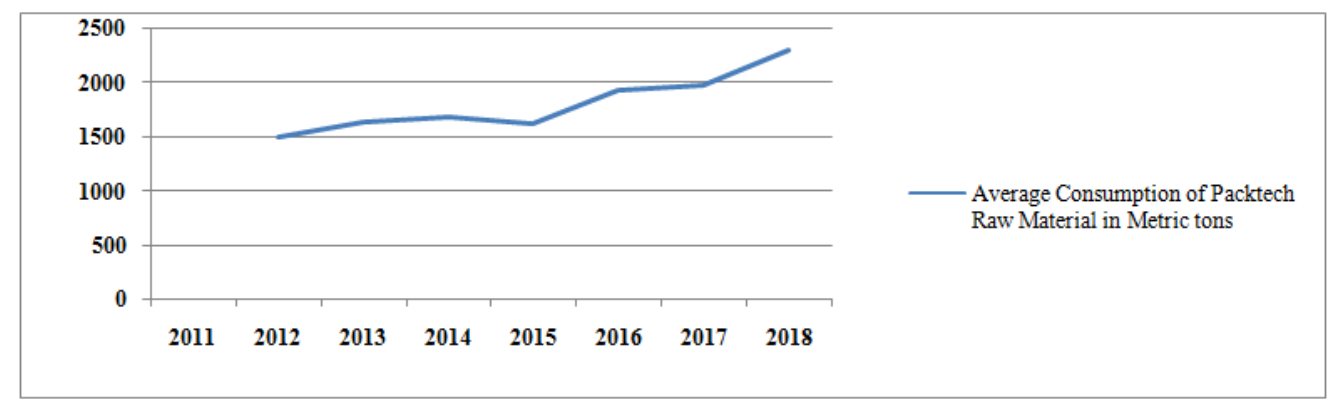

Graph 1: Packtech Industry Raw Material Consumption Statuses (Jaipur District).

\section{Source Primary Data}

Interpretation Graph reveals that average consumption of raw material since 2012 is increasing continuously except year 2015. In view of age of sample units, 14 unit's consumption data is used in above graph. Graph line grows in right upward direction which shows that the manufacturing unit's productivity increases in comparison of 2012. Manufacturing units were using 1496 metric tons raw materials in 2012 while in 2018 using 2310 metric ton raw material.

\section{MATERIAL AND METHOD}

Data provided by Rajasthan Plastic Association total 22 manufacturing industries identified in Jaipur district. Complete 18 responses gather from the owner of Packtech manufacturing unit. 3 non-responses and 1 unit closed in 2005, subtracted from the total sample size. Data gathered through the questionnaire was subjected to frequency counts to find the response for each individual question. On the basis of General information of organization, researcher identified the micro and small Packtech industries. The analysis and interpretation of data is carried out in two phases. In first phase questionnaire analysis has compiled item wise frequency under MSME amendment bill 2018. This amendment bill amends section 7 of the Micro, Small and Medium Enterprises Development Act, 2006. It was introduced on July 23, 2018. The bill reclassifies micro, small and medium enterprises as given within the original act below.

Table 3: Reclassification of MSMEs

\begin{tabular}{|c|c|c|c|}
\hline \multicolumn{4}{|c|}{ Change in Classification of MSME's } \\
\hline \multirow[b]{2}{*}{$\begin{array}{c}\text { Type of } \\
\text { Industries }\end{array}$} & \multicolumn{2}{|c|}{ MSME Act, 2006} & MSME Bill, 2018 \\
\hline & $\begin{array}{c}\text { Investment in Plant and } \\
\text { Machinery }\end{array}$ & $\begin{array}{l}\text { Investment in } \\
\text { Equipment }\end{array}$ & $\begin{array}{c}\text { New Classification: Annual } \\
\text { Turnover }\end{array}$ \\
\hline Micro & 25 lakh & 10 lakh & 5 crore \\
\hline Small & 25 lakh to 5 crore & 10 lakh to 2 crore & 5 to 75 crore \\
\hline Medium & 5 to 10 crore & 2 to 5 crore & 75 to 250 crore \\
\hline
\end{tabular}

Source: Medium, Small and Micro Enterprises Development (Amendment) Bill, 2018 (MSME, 2018) 
The Classification based on annual turnover instead of investment to stagnation of industries to change business ecosystem and trends. On the basis of turnover Jaipur Packtech industry has consist of micro and small industries. There is no medium level industry exist within the Packtech industry. The growth of Packtech industry pulls by the adverse PESTEL factors while favorable factors push the industry for growth

Table 4: PESTEL Analyses

\begin{tabular}{|c|c|c|}
\hline Categories & Industry Situation & Potential Impact \\
\hline Political Impact & $\begin{array}{l}\text { Government policy } \\
\text { Ministry of Textiles has undertaken several } \\
\text { developmental activities that are oriented towards } \\
\text { providing necessary support to promote growth of } \\
\text { Technical Textile industry in India through FY plans and } \\
\text { Funding schemes. } \\
\text { GoI and federation of India Chamber of Commerce } \\
\text { jointly organised the Technotex for increase research and } \\
\text { development to specific sector of Packtech. } \\
\text { Political stability } \\
\text { Central and state governments supported in the form of } \\
\text { establishment of textile parks, research centers, } \\
\text { international collaboration with foreign institutes and } \\
\text { laboratories, training facilities etc. is also playing a } \\
\text { significant role in the sector's progress (Arora, 2019). } \\
\text { Tax policy } \\
\text { Government policy for Petro based Packtech Industry } \\
\text { Investment Subsidy of } 60 \% \text { of State tax due and } \\
\text { deposited, for ten years; and } 6 \text { Employment Generation } \\
\text { Subsidy up to } 10 \% \text { of State tax due and deposited, for ten } \\
\text { years (Government of Rajasthan (Finance Department), } \\
\text { 2018) p.16. } \\
\text { Funding grants and initiatives } \\
\text { To promote Technical Textile sector Ministry of Textile } \\
\text { has launched various schemes for funding grants and } \\
\text { initiatives } \\
\text { Technology Mission on Technical Textile (TMTT) and } \\
\text { two mini mission for removal the impediments } \\
\text { hampering the production of Technical Textile industry } \\
\text { to meet the growing domestic demand (Ministry of } \\
\text { Textile, } 2018 \text { ) p; } 151-158 \text {. } \\
\text { Trade Restrictions } \\
\text { Packaging bags are now among the worlds most-banned. } \\
\text { The United Nations counted } 127 \text { nations that have banned } \\
\text { or taxed bags-and bag regulations have proliferated fast, } \\
\text { especially at the local level (Parkar, } 2019 \text { ). } \\
\text { The government's ban on polythene and plastic items } \\
\text { (Beniwal, } 2019 \text { ) will disrupt the supply chain, raise the } \\
\text { cost of goods from milk to biscuit packets, and impact the } \\
\text { food processing and consumer goods auto industry and } \\
\text { construction industries. }\end{array}$ & $\begin{array}{l}\text { There has been growth within the } \\
\text { sector and this growth will } \\
\text { continue. } \\
\text { The Technical Textile industry in } \\
\text { India is estimated to be valued at } \\
\text { Rs. } 73,688 \text { crore in } 2013-14 \text { and is } \\
\text { projected to grow to Rs. } 92,499 \\
\text { crore by } 2015-16 \text { and Rs. } 1,16,217 \\
\text { crore by } 2017-18 \text {. } \\
\text { The industry has witnessed a } \\
\text { growth of } 12.4 \% \text { over the last five } \\
\text { years driven mainly by the growth } \\
\text { witnessed in Packtech. }\end{array}$ \\
\hline
\end{tabular}




\begin{tabular}{|c|c|c|}
\hline Economic Impact & $\begin{array}{l}\text { Economic Situation } \\
\text { It is a multi-million industry and very competitive at } \\
\text { domestic level. It was identified as an area of interest of } \\
\text { other industries development. } \\
\text { Packtech is the segment of Technical Textiles which has } \\
\text { a share of } 43 \% \text { of the entire Indian Technical Textile } \\
\text { market. According to the Packaging Industry Association } \\
\text { of India, the Indian packaging industry was the fifth- } \\
\text { largest in the world in } 2016 \text { (Wisconsin Economic } \\
\text { Development Corporation, } 2017 \text { ). } \\
\text { Growth } \\
\text { There has been significant growth in this industry and } \\
\text { estimated to grow by } 11 \% \text { which is higher than global } \\
\text { growth of Packtech industry. } \\
\text { The packaging industry is increasingly becoming } \\
\text { technology-oriented with innovations driving the market; } \\
\text { this is expected to lead to packaging that increases shelf } \\
\text { life, reduces cost and is light weight (India Brand Equity } \\
\text { Foundation(IBEF), 2018). } \\
\text { This industry is highly sensitive to the prices of } \\
\text { HDPE/PP granules which are its key raw materials } \\
\text { constituting about } 60 \% \text { of the total input. Prices of } \\
\text { polymer granules increasing sharply, the woven sack } \\
\text { manufacturers are finding it increasingly difficult to } \\
\text { maintain competitive prices of their bags (ICRA } \\
\text { Management Consulting, 2015)p; } 110 \text {. }\end{array}$ & $\begin{array}{l}\text { The per capita consumption of } \\
\text { polymers in India during } 2014-15 \\
\text { was just } 10.5 \mathrm{~kg} \text { as compared to } \\
109 \mathrm{~kg} \text { in USA, } 45 \mathrm{~kg} \text { in China and } \\
32 \mathrm{~kg} \text { in Brazil. India is expected } \\
\text { to be among the top ten packaging } \\
\text { consumers in the world by } 2016 . \\
\text { The low level of per capita plastics } \\
\text { consumption in India is indicative } \\
\text { of the massive growth potential of } \\
\text { the plastic industry (FICCI, } 2016 \text { ). } \\
\text { There have been potential areas } \\
\text { like circularity industry, through } \\
\text { recycle, reuse and reproduce for } \\
\text { sustainable business. Circularity } \\
\text { industry of Packtech industry is } \\
\text { economically beneficial for all } \\
\text { stake holders from supplier to user } \\
\text { as it's reduce the resource } \\
\text { utilization in terms of raw material, } \\
\text { energy and natural resources. } \\
\text { Investment opportunities in } \\
\text { recycled Packtech Industry to } \\
\text { generate the employment to } \\
\text { semiskilled persons. } \\
\text { Circulatory industry reduces the } \\
\text { cost of environmental problem; } \\
\text { provide the solution of } \\
\text { infrastructure development and } \\
\text { waste management solution for } \\
\text { thrust problem of waste } \\
\text { management. }\end{array}$ \\
\hline
\end{tabular}




\begin{tabular}{|c|c|c|}
\hline $\begin{array}{l}\text { Social } \\
\text { Impact }\end{array}$ & $\begin{array}{l}\text { Demographics of the Market } \\
\text { Packaging industry represents the single-largest sector of } \\
\text { plastics use and accounts for } 35 \text { per cent of plastic } \\
\text { consumption (Toxics Link, 2014). } \\
\text { Consumption Patterns } \\
\text { Packtech applications area covers various industries } \\
\text { including automobiles, civil engineering and } \\
\text { construction, agriculture, healthcare, industrial safety and } \\
\text { personal protection(Flexituff International Limited, } \\
\text { 2016). } \\
\text { Cultural Factors } \\
\text { Busy lifestyles ensure the prevalence of eating and } \\
\text { drinking on the go, and smaller pack sizes lend } \\
\text { themselves to this trend for ready-to-eat meals which } \\
\text { gaining high traction, owing to busy work schedules, } \\
\text { rising number of working women, and shift toward on- } \\
\text { the-go consumption, which is, in turn, expected to ascend } \\
\text { the utilization of packaging (Mordor intelligent, 2018) } \\
\text { Lifestyle Trends } \\
\text { 2017 onwards, there has been a revived interest in } \\
\text { sustainability focused specifically on packaging. This is } \\
\text { reflected in central government and municipal } \\
\text { regulations, consumer attitudes and brand owner values } \\
\text { communicated via packaging (Smithers, 2018). } \\
\text { Changes in Consumer Purchasing Habits } \\
\text { In growing economy, rising incomes in the hands of a } \\
\text { young population, expansion in the availability of } \\
\text { products and services and easy availability of credit all } \\
\text { has given rise to new consumer segments and a rising } \\
\text { acceptability of debt, whether it is mobile phones, credit } \\
\text { cards, organized retail, people clearly seem to be } \\
\text { spending more, particularly on discretionary items, } \\
\text { packed fast and ready-to-serve food, Beverages, Ready to } \\
\text { eat food, Pre-cooked food due to nuclear family system } \\
\text { (Dey, 2017). }\end{array}$ & $\begin{array}{l}\text { The industry, which employs about } \\
5 \text { million people directly and three } \\
\text { times more indirectly, will } \\
\text { continue to grow due to rapid } \\
\text { change across the industry. } \\
\text { Organised retail and e-commerce } \\
\text { boom, which offer huge potential } \\
\text { for future growth of retailing, will } \\
\text { continue to support the packaging } \\
\text { industry (Aggarwal, 2018). } \\
\text { Indian consumers are spending } \\
\text { their money on various items has } \\
\text { changed. The penetration of } \\
\text { internet and social media has } \\
\text { increased; as a result the } \\
\text { purchasing behavior of Indian } \\
\text { consumers has changed } \\
\text { dramatically. Urbanization is a } \\
\text { constant phenomena in India and is } \\
\text { influencing the life style and } \\
\text { buying behavior of the consumers } \\
\text { (Dey, 2017) as well industrial } \\
\text { consumption of raw material. }\end{array}$ \\
\hline
\end{tabular}




\begin{tabular}{|c|c|c|}
\hline $\begin{array}{l}\text { Technological } \\
\text { Impact }\end{array}$ & 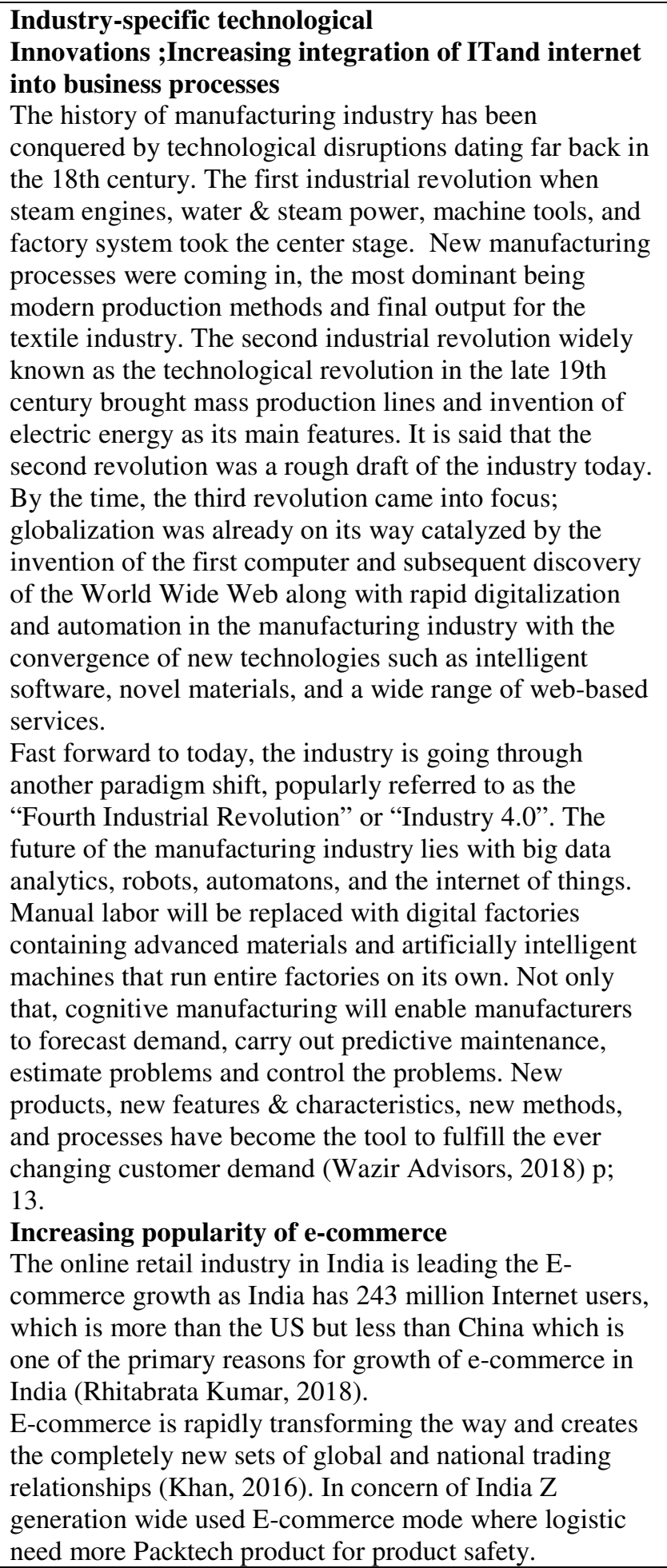 & $\begin{array}{l}\text { Packtech industry is highly capital } \\
\text { intensive and labour force is } \\
\text { required highly skillful to handle } \\
\text { automation process of } \\
\text { manufacturing. }\end{array}$ \\
\hline
\end{tabular}




\begin{tabular}{|c|c|c|}
\hline Environmental & 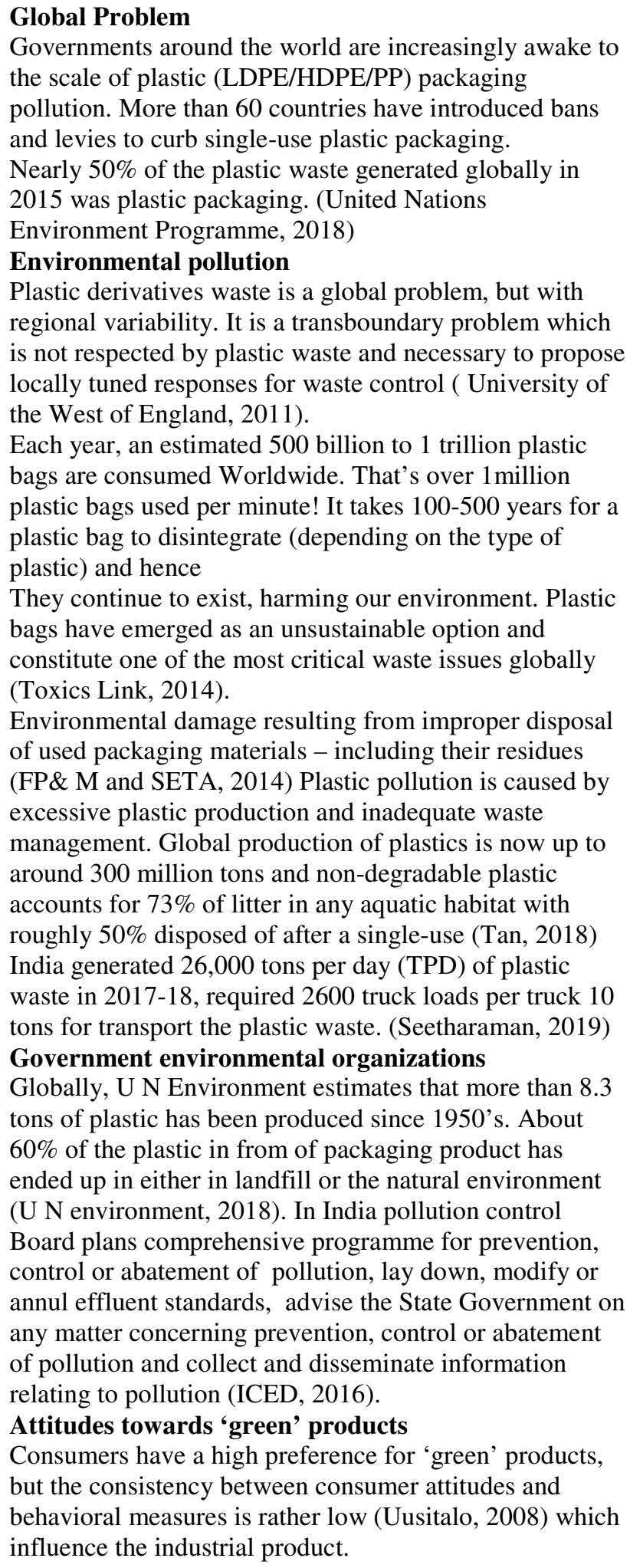 & $\begin{array}{l}\text { More prudent actions need to be } \\
\text { considered rather than an outright } \\
\text { ban (Sundaresan, 2015) } \\
\text { Recycling would go a long way to } \\
\text { sustain the Packtech industry } \\
\text { Need to take EPR solution for } \\
\text { channelize the industry. } \\
\text { Extended Producers Responsibility } \\
\text { for the establishment of waste } \\
\text { Management system and green } \\
\text { production (Govt. of India, 2016) } \\
\text { to prevent the plastic leakage in } \\
\text { environment, pricing of carry bag } \\
\text { is not as effective as consumer pay } \\
\text { higher for their comfort. }\end{array}$ \\
\hline
\end{tabular}




\begin{tabular}{|c|c|c|}
\hline $\begin{array}{l}\text { Legal } \\
\text { Impact }\end{array}$ & $\begin{array}{l}\text { Trade regulation } \\
\text { The Expert Committee on Technical Textiles (ECTT) } \\
\text { constituted by the Ministry of Textiles has also } \\
\text { recommended mandatory prescriptions for certain items. } \\
\text { One of the major deterrents for the expansion of usage of } \\
\text { many technical textiles products is absence of standards } \\
\text { and regulatory legislation in India (Mintstry of Textile, } \\
2012 \text { ). Government of India has recently notified } 207 \\
\text { HSN Codes from Technical Textiles and working on } \\
\text { standards formulation. } \\
\text { Environmental laws } \\
\text { In February } 2011 \text {, the Ministry of Environment and } \\
\text { Forests banned the use of plastic materials in sachets for } \\
\text { storing, packing or selling. New rules stipulate that } \\
\text { plastic carry-bags must not be less than } 40 \text { microns thick } \\
\text { less than } 8 \text { inches x } 12 \text { inches in size revised } 50 \text { microns; } \\
\text { earlier, the minimum thickness required was } 20 \text { microns. } \\
\text { Thinner plastics are more difficult to dispose off. Plastic } \\
\text { carry-bags cannot be made available to consumers free of } \\
\text { cost; the municipal authorities have been asked to } \\
\text { determine suitable price for these bags (India Brand } \\
\text { Equity Foundation(IBEF), 2018). }\end{array}$ & $\begin{array}{l}\text { The legal environment is barriers } \\
\text { towards this venture due to the } \\
\text { banning of Packtech Product. In } \\
\text { most parts of India, the bans have } \\
\text { been ineffective due to various } \\
\text { reasons, ranging from slack } \\
\text { enforcement by the administration } \\
\text { to lack of cost-effective } \\
\text { alternatives (Toxics Link, 2014) p; } \\
5\end{array}$ \\
\hline
\end{tabular}

\section{Source Secondary Data}

On the basis of PESTEL analysis Packtech industry pull and push factors identified through the intense interview of the Packtech manufacturer. Eight factors have selected amongst 38 factors based on bibliometry. The factors are raw material, skilled man power, technology, value addition government policy, research development, quality product and design of packaging which influence the growth of micro and macro Packtech industry

Table 5: Pull \& Push Factor of Packtech Industry

\begin{tabular}{|c|c|c|}
\hline Factors & Pull Factors & $\begin{array}{l}\text { Push Factors } \\
\end{array}$ \\
\hline Raw material & $\begin{array}{l}\text { 1) Life spun of HDPE/LDPE/PP500-1000years } \\
\text { creates environmental issue. 2) Land fill } \\
\text { problem 3) Plastic waste collection challenge } 4 \text { ) } \\
\text { Non degradable for long time 5) In India, there } \\
\text { are three common ways of getting rid of plastics: } \\
\text { by dumping them in landfills, by burning them } \\
\text { in incinerators or by littering them cause } \\
\text { Environmental problem. }\end{array}$ & $\begin{array}{l}\text { 1) Inexpensive ,non-polar ,hydrophobic } \\
\text { Polymer, HDPE,LDPE and PP are wide } \\
\text { applications 2) high strength to weight } \\
\text { ration, stiffness and toughness, safe \& } \\
\text { hygiene, energy saving and material } \\
\text { recycling 3) Versatility, low cost and high } \\
\text { chemical stability 4) Versatile applications } \\
\text { 5)highest use of raw material in packaging as } \\
\text { PE 30\% and PP 18\% strength, Stress } \\
\text { resistance, flexibility and durability }\end{array}$ \\
\hline $\begin{array}{l}\text { Skilled man } \\
\text { power }\end{array}$ & $\begin{array}{l}\text { 1) Automation of industry has less employment } \\
\text { for semi and unskilled manpower }\end{array}$ & $\begin{array}{l}\text { 1) Automation of industry developed skilled } \\
\text { manpower through technical institutions. }\end{array}$ \\
\hline Technology & $\begin{array}{l}\text { 1)Customization very costly, heavy investment } \\
\text { required for automatic machines and plant 2) } \\
\text { Single use and environmental issue }\end{array}$ & $\begin{array}{l}\text { 1) Automation solutions and IT equipment } \\
\text { that can enable the industry to become leaner } \\
\text { and more agile. 2) Blow fills seal process, } \\
\text { mass encoding and production, anti counter } \\
\text { feit Packaging Technology. }\end{array}$ \\
\hline Value addition & $\begin{array}{l}\text { 1) Creates complications for life cycle and } \\
\text { increase toxicity in environment }\end{array}$ & $\begin{array}{l}\text { 1) Increase the strength of Packtech product, } \\
\text { pliable and flexible, fire retardants to } \\
\text { discourage ignition and burning, and UV } \\
\text { stabilizers to prevent degradation when } \\
\text { exposed to sunlight }\end{array}$ \\
\hline $\begin{array}{l}\text { Government } \\
\text { policy }\end{array}$ & $\begin{array}{l}\text { 1) Increasing politicization towards the latter end } \\
\text { of the life cycle, that is, plastic as waste and } \\
\text { pollution }\end{array}$ & $\begin{array}{l}\text { 1) Plastic crisis: attempts to construct (a) a } \\
\text { circular plastics economy and (b) global } \\
\text { plastics conventions or treaties. }\end{array}$ \\
\hline
\end{tabular}




\begin{tabular}{|l|l|l|}
\hline $\begin{array}{l}\text { Research \& } \\
\text { Development }\end{array}$ & 1) Plastic waste reduction and end-of-life issues & $\begin{array}{l}\text { 1) New packaging solutions bio packaging } \\
\text { and eco friendly packaging }\end{array}$ \\
\hline Quality Product & $\begin{array}{l}\text { 1) Environmental pollution trough Polymerized } \\
\text { polymer Packtech }\end{array}$ & 2) Safety and hygiene of polymers \\
\hline $\begin{array}{l}\text { Design of } \\
\text { Packaging }\end{array}$ & $\begin{array}{l}\text { 1)Design for Environmental (DfE) } \\
\text { 2) Less eco friendly }\end{array}$ & $\begin{array}{l}\text { 1) Design for Sustainability } \\
\text { 2) Useful in retailing and business } \\
\text { sustainability }\end{array}$ \\
\hline
\end{tabular}

\section{Source Secondary Data}

The life span of polymerized Packtech material is 500-1000 depends on the additive and quality of polymers with functional application in various industries. These polymerized Packtech has single usage which causes the environmental pollution as landfills while the Packtech is essential for various industries growth.

\section{RESULT ANALYSIS}

To measure the pull and push factors of industry growth, data was collected through Likert scale which measures 1-5 scale. The graph represents the responses of Packtech manufacturers for pull \& push industry growth factor.

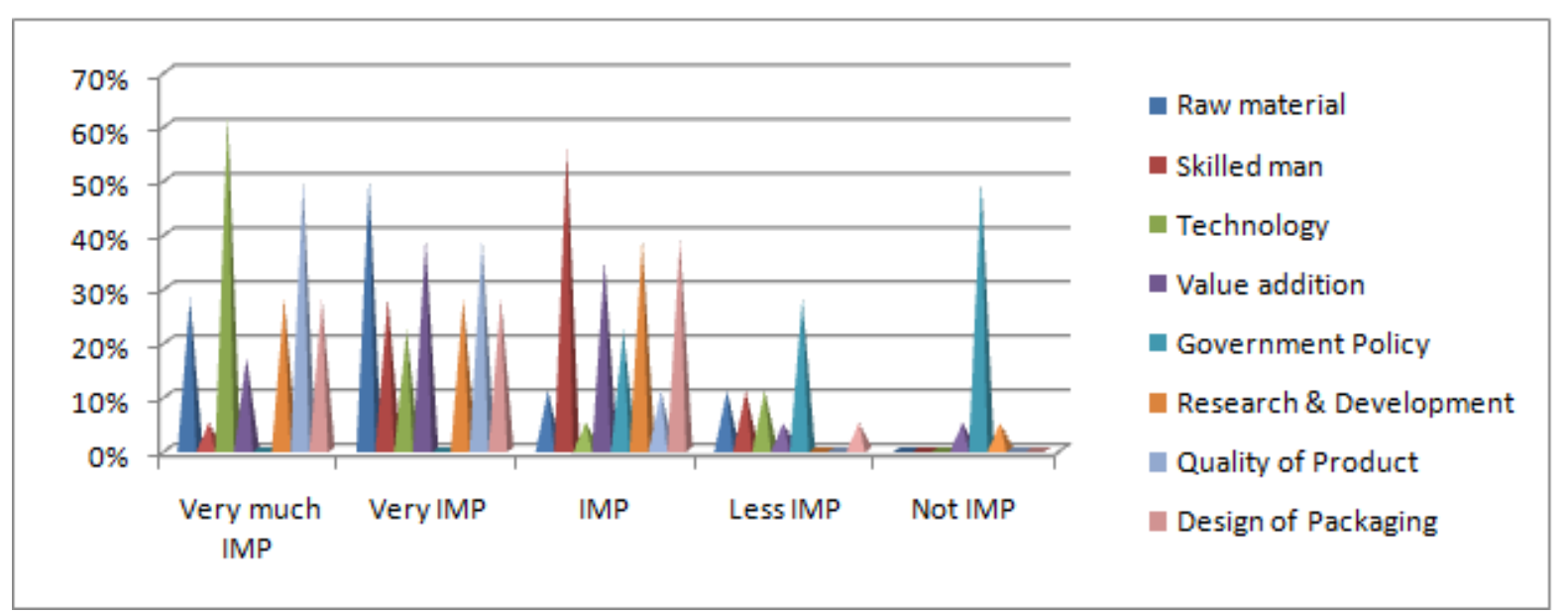

Graph 2: Responses for Pull \& Push Factors of Industry Growth.

\section{Source Primary Data by Author}

Friedman test is used to test for differences between pull and push dependent factors of industry growth. This test is the non-parametric alternative to the one-way ANOVA with repeated measure and used since sample is small \& observations are collected on Likert Scale.

Table 6: Friedman Test

\begin{tabular}{|c|c|}
\hline \multicolumn{2}{|c|}{ Friedman Test } \\
\hline $\mathrm{N}$ & 16 \\
\hline Chi-Square & 48.898 \\
\hline $\mathrm{df}$ & 7 \\
\hline Asymp. Sig. & .000 \\
\hline
\end{tabular}


Table 7: Friedman Test Mean Rank

\begin{tabular}{|c|c|}
\hline \multicolumn{2}{|l|}{ Ranks } \\
\hline Attributes & Mean Rank \\
\hline Raw Material Affinity to Product & 5.06 \\
\hline Skilled Man Power & 3.66 \\
\hline Technology & 5.84 \\
\hline Value Addition & 4.31 \\
\hline Government Policy & 1.38 \\
\hline Research Development & 4.66 \\
\hline Quality of Product & 6.25 \\
\hline Design of Packaging & 4.84 \\
\hline
\end{tabular}

The chi-square value is 48.898 and p-value is 0.000 . This result is significant at the level of 0.05 p-values. Hence, null hypothesis is rejected and there is a difference in importance of attributes is exists. Post hoc testing using; Wilcoxon Signed-Rank Test is required to find out the pair wise differences.

Table 8: Wilcoxon Signed -Rank Test

\begin{tabular}{|c|c|c|c|c|c|c|c|}
\hline \multicolumn{8}{|c|}{ Wilcoxon Signed-Rank Test } \\
\hline Attributes & $\begin{array}{c}\text { Skilled Man } \\
\text { Power }\end{array}$ & $\begin{array}{c}\text { Technolo } \\
\text { gy }\end{array}$ & $\begin{array}{c}\text { Value } \\
\text { Addition }\end{array}$ & $\begin{array}{c}\text { Government } \\
\text { Policy }\end{array}$ & \begin{tabular}{|c|} 
Research \\
Developm \\
ent
\end{tabular} & $\begin{array}{l}\text { Quality of } \\
\text { Product }\end{array}$ & $\begin{array}{c}\text { Design of } \\
\text { Packagin } \\
g\end{array}$ \\
\hline Raw Material Affinity to Product & .057 & .154 & .343 & .001 & .458 & .142 & .564 \\
\hline Skilled Man Power & & .024 & .244 & .001 & .127 & .001 & .083 \\
\hline Technology & & & .061 & .000 & .099 & .854 & .101 \\
\hline Value Addition & & & & .001 & .936 & .010 & .366 \\
\hline Government Policy & & & & & .001 & .000 & .001 \\
\hline Research Development & & & & & & .071 & .685 \\
\hline Quality of Product & & & & & & & .013 \\
\hline
\end{tabular}

Result shows Raw material is more important than skilled man and Government policy while Technology, Research Development, Quality of Product and Design of Packaging is more important than Raw Material. Similarly the each row shows the importance than other comparative factors. The yellow areas show the significant negative difference with the comparative factors.

\section{CONCLUSIONS}

This study evaluated dimension of PESTEL analysis to determine to what extent macro environmental conditions is appropriate to realize the goals and targets of industry. In the present study, pull and Push factors are identified on the basis of nature of industry product .Direct relationship carried out between the PESTLE factors and pull \& push factors of industry growth. The material consumption growth and the nature of polymerized Packtech material product both increase the environment problems. The study provide the road map for the balance between the pull and push factors through suitable solution as recycling, circular industry and awareness among user. This study further extended for Packtech green production and awareness level within the industry.

\section{REFERENCES}

1. University of the West of England. (2011). Science for Environment Policy-Plastic Waste: Ecological and Human Health Impacts. Europe: European Commission's Directorate-General Environment. 
2. Aggarwal, D. (2018, December 1). This industry is packaging a lot of prospects; worth a good look. Retrieved November 10, 2019, from www.economictimes.indiatimes.com: https://economictimes.indiatimes.com/markets/stocks/news/this-industry-ispackaging-a-lot-of-prospects-worth-a-good-look/articleshow/66892561.cms?from=mdr

3. Arora, S. (2019, 04 16). India An Emerging Market \& Global Manufacturing Hub for Technical Textiles. Retrieved 11 5, 2019 , from www.wazir.in: https://wazir.in/india-an-emerging-market-global-manufacturing-hub-for-technical-textiles

4. Beniwal, B. P. (2019, October 1). Modi wants to take away India's plastic bags and spoons. Retrieved November 10, 2019, from economictimes.indiatimes.com: https://economictimes.indiatimes.com/news/politics-and-nation/modi-wants-to-takeaway-indias-plastic-bags-and-spoons/articleshow/71386214.cms

5. Bindu Sharma, S. S. (2020). Packtech Industry-An Industrial \& Environmental. International Journal of Recent Technology and Engineering (IJRTE) , 452-488.

6. Collier, U. (1997). Think globally, act locally?: Local climate change and energy policies in Sweden and the UK. Global Environmental Change, 25-47.

7. Compare Infobase Limited. (2011, Aug 1). Petrochemical Industry. Retrieved 12 30, 2019, from business.mapsofindia.com: https://business.mapsofindia.com/petrochemical

8. Dey, S. (2017). A Study on Changing Buying Behaviour of Indian Customers. Global Journal of Marketing Management and Research, 1-4.

9. Feil, A. A. (2019). Sustainability Indicators for Industrial Organizations:Systematic Review of Literature. Sustainability, 1-15.

10. FICCI. (2016). Plastic Packaging- the sustainable chioce. New Delhi: Tata Strategic management Group.

11. Flexituff International Limited. (2016). Management Discussion and Analysis. New Delhi: F lexituff International Limited.

12. FP\& M and SETA. (2014). A profile of the packaging sub-sector. South Africa: Fiber Processing \& Manufacturing Sector Education and Training Authoroty.

13. Giljum, S. (2014). Global Patterns of Material Flows and their Socio-Economic and Environmental Implications: A MFA Study on All Countries World-Wide from 1980 to 2009. Resources, 319-339.

14. Government of Rajasthan (Finance Department). (2018). Rajasthan Investment Promotion Scheme - 2014. Jaipur: Finance Department.

15. Govt. of India. (2016). Government Notifies Plastic Waste Management Rules, 2016. New delhi: Ministry of Environment and Forests.

16. Golshahr, Alireza, et al. "Multiwall carbon nanotube reinforced silicone for aerospace applications." Int. J. Mech. Prod. Eng. Res. Dev 8.4 (2018): 743-752.

17. Hymavathi, D., G. Prabhakar, and B. B. Sarath. "Biodiesel production from vegetable oils: an optimization process." Int J Chem Petrochem Technol, 4 (2), 2130 (2014).

18. ICED. (2016). Effectiveness in the Functioning of State Pollution Control Board. jaipur: ICED.

19. ICRA Management Consulting. (2015). Baseline survey of the Technical Textile industry in India. New Delhi: ICRA Management Consulting Services Limited.

20. India Brand Equity Foundation(IBEF). (2018). Flexible Packaging Industry. new delhi: IBEF.

21. Juerg. (2009, April 11). Plastic bags and plastic bottles - CO2 emissions during their lifetime. Retrieved Feb 04, 2020, from timeforchange.org: https://timeforchange.org/plastic-bags-and-plastic-bottles-co2-emissions-during-their-lifetime/ 
22. Khan, A. G. (2016). Electronic Commerce: A Study on Benefits and Challenges in an Emerging Economy. Global Journal of Management and Business Research , 1-4.

23. Lieber, S. L. (2016, 05 10). The concept of material consumption. Retrieved 06 11, 2020, from www.materialflows.net: http://www.materialflows.net/the-concept-of-material-consumption/

24. Ministry of Environment and Forests. (2016). The Gazette of India: Extraordinary. New Delhi: Govt. of India.

25. Ministry of Finance, Government of India. (2016). Demonetization and Cashless Economy. New Delhi: Ministry of Finance, Government of India.

26. Ministry of Textile. (2018). Annual Report 2017-2018. New Delhi: Government of India.

27. Mintstry of Textile. (2012). Compendium on Standards inTechnical Textiles sector. New Delhi: Govt. of India.

28. Mordor intelligent. (2018). Packaging Industry in India - Growth, Trends, and Forecast (2019 - 2024). Retrieved November 10, 2019, from www.mordorintelligence.com: https://www.mordorintelligence.com/industry-reports/packaging-industry-inindia

29. MSME. (2018, 03 22). The Micro, Small and Medium Enterprises. Retrieved 5 7, 2020, from MSME: http://164.100.47.193/Refinput/New_Reference_Notes/English/MSME.pdf

30. Mutar, Mohammed Ail, and Noor Mohammed Abdul Hassan. "Synthesis and Characterization Of New Alkyd Resins (Short, Medium And Long) Based On Sunflower Oil And Linoleic Acid As Binder For Paints." International Journal of Chemical \& Petrochemical Technology (2017): 1-16.

31. National Industrial Classification. (2008, 07 9). Code NIC 2008 - C MANUFACTURING. Retrieved 06 27, 2020, from nicode.su: http://nicode.su/index.php?url=ocved\&id=261

32. Oleiwi, Jawad K., Sihama I. Salih, and Hwazen S. Fadhil."Water Absorption and Thermal properties of PMMA Reinforced by Natural Fibers for Denture Applications." International Journal of Mechanical and Production Engineering Research and Development 8.3 (2018): 1105-1116.

33. Parkar, L. (2019, April 17). Plastic bag bans are spreading. But are they truly effective? Retrieved November 10, 2019, from www.nationalgeographic.com: $\quad$ https://www.nationalgeographic.com/environment/2019/04/plastic-bag-bans-kenya-to-usreduce-pollution/

34. Rhitabrata Kumar, D. A. (2018). An Analysis of the Rise of E-Commerce in India. Symbiosis Institute of Management, 1-20.

35. Seetharaman, G. (2019, September 22). How plastic ban will affect businesses and consumers. Retrieved November 10, 2019, from www.economictimes.indiatimes.com: https://economictimes.indiatimes.com/industry/indl-goods/svs/paper-/-wood-/glass/-plastic/-marbles/how-plastic-ban-will-affect-businesses-and-consumers/articleshow/71236532.cms?from=mdr

36. Smithers. (2018). Four key trends that will shape the future of packaging to 2028. Retrieved November 10, 2019, from www.smithers.com: https://www.smithers.com/resources/2019/feb/future-packaging-trends-2018-to-2028

37. Strategy\& Booz \& Company. (2015). Plastic Packaging- the sustainable and smarter choice . New delhi: FICCI.

38. Sundaresan, N. B. (2015). Plastic Packaging the sustainable and smarter chioce. New delhi: Strategy\& Booz \& Company.

39. Tan, H.-S. (2018). Green products consumption behaviour among industrial engineering. The 2 nd International Conference on Eco Engineering Development 2018 ( (pp. 2-11). Indonesia: IOP Publishing.

40. Toxics Link. (2014). Plastics and the Environment-Assessing the Impact. New Delhi: Toxics Link.

41. Trucost. (2016). Plastics and Sustainability., North America: Trucost. 
42. U N environment. (2018, June 5). Our planet is drowning in plastic pollution. Retrieved november 13, 2019, from www.unenvironment.org: https://www.unenvironment.org/interactive/beat-plastic-pollution/

43. United Nations Environment Programme. (2018). SINGLE-USE PLASTICS:A Roadmap for Sustainability. USA: The International Environmental Technology Centre.

44. Uusitalo, J. R. (2008). Preference for green packaging in consumer product choices - Do consumers care? International Journal of Consumer Studies , 516-525.

45. Wazir Advisors. (2018). Building a New Age Textile Industry. Mumbai: FICCI.

46. Weisz, H. (2006). The physical economy of the European Union: Cross-country comparison and determinants of material consumption. Ecological Economics , 676-698.

47. Wisconsin Economic Development Corporation. (2017, November 1). India: the world's fifth-largest packaging industry. Retrieved November 10, 2019, from www.wedc.org: https://wedc.org/export/market-intelligence/posts/india-worlds-fifthlargest-packaging-industry/

48. Wood, L. (2019, April 8). India Waste to Energy and Waste Management Market 2019-2025 - Opportunities, Economics, Technologies, Market Trends, Challenges \& Outlook. Retrieved Feb 4, 2020, from www.businesswire.com: https://www.businesswire.com/news/home/20190408005577/en/India-Waste-Energy-Waste-Management-Market-2019-2025

49. Zulfiqar Ali, S. B. (2016). Basic statistical tools in research and data analysis. Indian Journal of Anaesthesia , 54-61. 